\title{
Micro finance: Emerging Challenges And Opening Vistas
}

\author{
${ }^{1}$ Dr. Anupama Sharma, ${ }^{2}$ Ms. Sumita Kukreja, ${ }^{3}$ Dr.Anjana Sharma \\ ${ }^{1,2}$ Asst. Professor Department of Business Administration, Maharaja Surajmal Institute, Janakpuri, Delhi \\ ${ }^{3}$ Asst.Professor Department of Tourism, Govt.P.G. College,Gurgaon,Haryana
}

\begin{abstract}
This research aims at highlighting the various types of financial need of the rural poor people living below the poverty line and the sources available to meet their diverse financial need. This is the right time to investigate the achievements of various schemes under Micro finance. According to an estimate globally 1.2 billion people live in extreme poverty (defined as subsisting on less than one dollar a day) of which $44 \%$ are in South Asia, 75\% live in rural areas in India. It has been observed that in India poverty is basically rural in character. More than $22 \%$ of Indian population lives below the poverty line even today. After nationalization, though the government initiated various development programmes in context to eradication of vicious circle of poverty (especially in rural area) but still the programmes have not gained the desired momentum. In the new development initiative the concept of micro finance has emerged as a solution to correct the imbalances of poverty. Micro finance is such a tool, which directly hits the poverty by helping poor or enabling them not only to survive but also to improve their standard of living. In this Present paper an attempt has been made to highlight the hurdles faced by the rural poor while dealings with banks, impact of various poverty alleviation programmes initiated by banks, NGOs, government, other institutes and challenges ahead.
\end{abstract}

Key Words: Micro-Finance, Self- Help Groups, Social- Transformation, Marginal and Small-Farmers, NABARD

The overwhelming majority of poor people in India are concentrated in rural area of the estimated 260 million Indians(or 26\% of the population who live in poverty, some 193 million(or 74\%) live in rural areas[Planning commission of India's definition of poverty].

\section{Introduction}

The catalytic role played by credit for accelerating the economic development has been well recognized all over the world. Since the inception of Central Economic Planning in 1950, the government identified the credit needs of the rural sector and framed policies conducive for the flow of institutional credit. Finance is one of the most fundamental inputs for economic activity, extension and development of any economy. Provision of financial services to the poor and underprivileged section of the society has always been in the focus of various programmes, which are run by the government since independence. Despite having a wide network of rural bank branches in India, which implemented specific poverty alleviation programmes that sought creation of selfemployment opportunities through bank credit, a large number of unprivileged poor masses still continued to remain outside from the field of formal banking system. Therefore, a need was felt for alternative policies, systems and procedures, saving and loan products, other complementary services and new delivery mechanisms, which would fulfill the financial requirements of the poor. The concept of Micro Credit has emerged in India as a new mechanism of lending over the past few years. Micro credit has evolved as a powerful mechanism to deliver financial services particularly credit to the section of the community that have been excluded from the services of the main stream institutions. It has been recognized and accepted as one of the new development paradigm for alleviating poverty through social and economic empowerment of the poor. "Micro credit is based on the premise that poor have skills, which remain unutilized or underutilized. It is not the lack of skills, which make the poor people poor..........charity is not the answer to poverty. It only helps poverty to continue. It creates dependency and takes away the individual's initiative to break through the wall of poverty. Unleashing of energy and creativity in each human being is the answer to poverty".

\section{Objectives:}

1. To study the impact of Microfinance programmes on the weaker section of society.

2. To explore the working of SHG Bank linkage programme.

3. To study the impact of Micro Finance especially on the rural women in context of their economic conditions.

4. To study the effectiveness of the micro finance programmes in the recent years.

The present study is based on the following research methodology. 


\section{Research Methodology}

Data collection Method

The study embodied both primary and secondary data.

Primary data has been collected by way of canvassing a questionnaire.

Secondary Data- In the present study the secondary data has been collected through RBI Bulletin, Economic Intelligence Service, and Center for Monitoring Indian Economy, Banking Statistics of India, Haryana Statistical Abstract, newspapers, journals and Internet.

\section{Sample size}

For the study we have selected the village Baliana from Rohtak District which is one among the 20 Districts in Haryana State. It has been chosen on the basis of convenience and feasibility to collect data on the random basis The sample selected comprise of farmers of different category namely marginal farmers and small farmers, artisans and private employees and self-employed persons including shop-keepers, potters and others.

\section{Tools of analysis}

Various tools of analysis have been used in the study as per the requirement such as \%age, growth rate and tabulation.

\section{Organization of the study:}

The study has been divided into five chapters.

The first chapters covers introduction the Rural Banking Development in India as well as in the Haryana State.

The second chapters talks about the concept of Micro credit-Genesis, growth and relevance.

The linkage between rural banking and Micro finance is being covered in the third chapter.

The fourth chapter covers the analysis part, while suggestions have been given the last chapter.

\section{Rural Banking Development in India:}

Banks have been enjoying a dominant position in the Indian financial sector and they are not merely economic entities but also engines of economic growth and social transformation. According to Webster's Dictionary," Banks are those institutions which deal in money. It is that institute, where money is deposited and withdrawn and loans and advances facilities are provided". The rural banking Development in India can be well studied in two parts namely:

- $\quad$ Banking Development before Independence

- Banking Development after Independence

\section{A) Banking Development before Independence}

Establishment of banking in India was first attempted in the year 1683 by Madras-based officers of the East India Company. The growth in Indian banking business till the beginning of the present century wasimost negligible. The foundation of the modern banking was laid during the early part of the nineteenth century with the establishment of the three presidency banks namely, the Bank of Bengal (1806), the Bank of Bombay (1840), the Bank of Madras (1846). The intention was to create a Central bank in the country with the monopoly of note issue and serve as banker's bank and a government bank. The year 1860 is considered to be a landmark in the banking history of India, as some of the well-known banks were formed the Bank of Upper India (1863), the Allahabad Bank (1865), the Bangalore Bank (1868). Then the Swadeshi Movement of 1906 gave rise to the Bank of India, the Indian Bank of Madras, the Central Bank of India, the Bank of Baroda and others. Prior to independence the concept of social/rural banking was not the main concern.

\section{B) Banking Development after Independence}

In the time period, between 1939 to1946, 422 banks were failed. Some more banks failed between 1947-59(approximately 630). From 1959-1980, 250 banks small-big banks failed and in the decade of 1980,4 major banks failed which was the major reason for losing the interest of public in banking system. The Independence of the country in August 1947 changed the whole approach towards commercial banking and Government came to recognize it as a positive instrument for faster economic development. After independence two major incidents took place. One was the implementation of Banking Regulation Act, 1949 and the other was the Nationalization of Banks. After independence govt. nationalized the RBI(January 1949) and in 1955 Govt. Nationalized the Impirical Bank of India, which is known as State Bank of India (SBI). In July 19,1969 the president V.V. Giri issued an ordinance nationalizing the 14 major scheduled commercial banks, whose deposits as on end June 1969 were not less than Rs.50 crores. Broadly, the step of nationalization was intended to 'accelerate' the achievement of the objectives of social control. The main purpose behind this step was to increase the number of banks branches in the rural area for uplifting the economic condition of the rural area as 
Micro finance: Emerging Challenges And Opening Vistas

the maximum number of banks branches were being opened in the urban/developed areas. On account of this reason government decided to merge The New Bank of India with PNB on $4^{\text {h }}$ December 1993.

\section{Development of Banking Sector in Rural Area}

In June 1969, total number of banks branches in India were 89, out of which 73 were scheduled commercial banks and 16 were non-scheduled commercial banks. The branches of commercial banks increased to 226, out of which 148 were scheduled commercial banks, 74 regional rural banks and 5 non-scheduled commercial banks in June 1980. In 1998, the branches further increased to 340, out of which state bank and its subsidiaries are 8 in number, 19 nationalized banks, 196 RRB's, 86 Scheduled commercial banks, 23 private banks and 1 non-scheduled commercial banks.

\section{Expansion of Banks Branches in Rural India}

India has a deep financial system, attributable in large part to the country's vast network of banks and other financial institutions including thousands of rural bank branches. The 1970s and 1980s saw a rapid expansion of India's financial system into rural areas. After nationalization commercial banks were required to open rural banks. The below mentioned table will help us in knowing about the proportion of rural bank branches in comparison to the total number of branches in India

Table 1.1, shows that in India, in 1969 only $22.5 \%$ of total bank branches were in rural area which increase to $57 \%$ in the year 1989 and in the year 2001 it decreased to $48 \%$ and further decreased to $45 \%$ in the year 2005. At present around $45 \%$ of the total bank branches have spread their network in rural area.

Rural Banks Branches in India on $3 \mathbf{1}^{\text {st }}$ March,2009
\begin{tabular}{|l|l|l|l|l|l|}
\hline Year & $\begin{array}{l}\text { Total Bank } \\
\text { Branch }\end{array}$ & Growth Rate & $\begin{array}{l}\text { Bank Branches } \\
\text { in Rural Area }\end{array}$ & Growth Rate & $\begin{array}{l}\text { \%age of Rural } \\
\text { bank Branches }\end{array}$ \\
\hline 1969 & 8321 & 0 & 1860 & 0 & 22.5 \\
1980 & 34588 & 28.7 & 16751 & 72.8 & 48.4 \\
1989 & 57197 & 7.3 & 32577 & 10.5 & 57 \\
1997 & 63513 & 1.4 & 32981 & .16 & 51.9 \\
2007 & 67525 & 1.58 & 32640 & -.26 & 48 \\
2009 & 69969 & .90 & 31967 & -.52 & 45 \\
\hline
\end{tabular}

Source: RBI Bulletin 1969-2009

Table-1.1

Expansion of Banking Industry in Haryana

Population Group wise turnover of Rural Banks Branches on 31 $1^{\text {st }}$ March,2009

\begin{tabular}{|l|l|l|l|l|}
\hline Year & $\begin{array}{l}\text { Banks Branches in } \\
\text { Rural Area }\end{array}$ & Growth rate & $\begin{array}{l}\text { Total Banks } \\
\text { Branches }\end{array}$ & Growth Rate \\
\hline 1969 & $264(54.0)$ & 0 & 489 & 0 \\
1980 & $414(53.1)$ & 5.2 & 779 & 5.4 \\
1990 & $739(57.7)$ & 7.9 & 1280 & 6.4 \\
1998 & $693(49.0)$ & -.8 & 1413 & 1.3 \\
2001 & $699(45.71)$ & .29 & 1529 & 2.74 \\
2007 & $704(41.6)$ & .18 & 1692 & 2.67 \\
2009 & $976(44.46)$ & 19.31 & 2195 & 14.86 \\
\hline
\end{tabular}

Source: Economic Intelligence Service, CMIE

Indication: Figures given in the brackets shows the percentage.

\section{Table-1.2}

Table 1.2, shows that in Haryana 54\% of the total bank branches were in rural area which decreased to $49 \%$ in the year 1998 and further to $44.46 \%$ in the year 2007. Further the table shows that in the year 1980 the growth rate in total bank branches in Haryana has been recorded to be 5.4 where as in the same year growth rate in rural area was 5.2. \%. In the year 2001 growth rate was 2.67 in total bank branches while it was .18\% in the rural area. The growth rate has increased in the year 2007 to $14.86 \%$ in total bank branches and in rural area in the same year the percentage is 19.31 . 
Micro credit aims to increase rural access to banking services and target credit at some specific activities and certain disadvantaged groups. Poor people represent a vast untapped market opportunity. Micro credit empowers the poor people and protects them from the moneylenders. It may also be considered a tool to give poor people the opportunity to participate in the economic life. The theoretical discussion about the impact of Micro credit on poverty reduction calls for thorough empirical research. Therefore, it is surprising that there are only a few solid empirical studies available on the possible poverty reducing effects of microcredit. A major problem is how to measure the contribution of micro credit.

\section{What does the Term Microfinance Mean?}

The Microfinance mean small \& tiny in size. Micro-credit is generally offered without any collateral.

On the other hand micro-finance is a financial service of small quantity provided by entrepreneurs, particularly women entrepreneurs, from low income households. These loans are generally offered without any collateral. Micro-finance is a provision of thrift, credit and other financial services and products of very small amount to the poor in rural, semi-urban or urban areas for enabling them to raise their income levels and improve living standards. The micro-finance approach or tool has emerged as an important development in banking for canalizing credit to rural people for poverty alleviation directly \& effectively. The RBI has issued comprehensive guidelines to banks in Feb. 2000 for promoting the system of micro credit \& enhancing the outreach of the suppliers of micro credit. The micro credit extended by banks to individual borrowers directly or through any agency is regarded as a part of bank's priority sector loans. The Self-Help Group Banks Linkage Programme is the major programme, which is implemented by commercial banks now for increasing the volume $\&$ outreach of micro credit. Twenty point programme is a closed example of Micro-finance. Central Govt. restarts it in 2005.

The role of Microfinance can't be ignored in India while 62\% people live in rural area and $80 \%$ people earned their livelihood from agriculture. So that microfinance may be such a tool which directly hits the poverty by helping poor or enabling them not only to survive but also to improve their standard of living.

\section{Need of credit by rural people}

To meet the diverse financial needs of rural masses is a big challenge, which requires improving the system of making an easy access to finance. Financial markets serve poor people badly as they don't have collateral and therefore are often neglected. High transaction costs and physical access to banking services in low population density makes the situation even worst. Finance is a very effective tool in providing economic opportunity and fighting poverty. Without access to credit, one avenue of opportunity i.e. self-employment is shut off. As a result the living condition of poor becomes worse. 21.8\% (as per NSSO data for 2004-05) of India's population lives below poverty line, which indicates government, need to put more efforts for making the poor people, availed of the basic necessities of life.

Major part of India's population depends on agriculture; the majority of which are marginal farmers or small farmers or landless farmers. They need a wide range of financial services for meeting their varied consumption needs. They can access finance from three major sources: -

- $\quad$ Formal source such as commercial banks, Post Office Network, Cooperative Banks \& others. These sources show lack of interest in providing financial support to the poor people because of high risk involved in the recovery of the funds. Even poor people don't find it attractive, as they demand for collateral, which they don't have, and because of high transaction costs involved in raising finance.

- $\quad$ Micro financing Institutions also known as Semi-formal Source is gaining popularity now a days specially SHG's (Self Help Groups). Micro financing Institutions provides varied types of micro credit as per the need of the poor. Even people find it more attractive because of the low transaction costs involved in it and no physical assets are required as collateral.

- Informal Source such as moneylenders, friends, relatives. Still most of the marginal farmers depend on this source because of easy availability of the funds. They usually charge high rate of interest but still are more popular among the poor rural households as they provide flexible services.

In a planned economy like India which primarily aims to ameliorate the conditions of the rural poor through creation of employment opportunities, improvement of skills and productivity of land and labour, banks are expected to play an active role in development irrespective of how they come-up, who own them and what they were doing up to now. The organization of co-operative credit system, the emergence/conversion of Imperial Bank of India into State Bank of India introduction of social control over banks and latter, the nationalization of major banks were to ensure that the banks no longer remained unconcerned with the needs of planned development but played an active role in improving the productivity of human and natural resources in India, in 
Micro finance: Emerging Challenges And Opening Vistas

the development of rural sector and for the uplift of poorer sections of society. The role of banks in the present context has to be viewed from this basic consideration.

The banks cannot have the same objectives as those of the national plan. Irrespective of at what stages our planning process stands or the detailed contents of the on going five-year plan. The principal objectives of national planning in India have always been and continue to be for a long time to come viz., removal of unemployment and under-employment through creation of additional employment opportunities. For this purpose, provide necessary technical and financial help so that (a) requisite assets are acquired by the poorer sections of the population, (b) their skills are improved so that their productivity increases and (c) institutional support is given to those who require it most. From these objectives, the main content of developmental role of banks in the rural sector follows.

(i) All bank loans are to be part and parcel of total development programming under the national five-year plan.

(ii) Loans are to be given for labour intensive schemes, which generate employment.

(iii) Loans are given to generate productive assets and increase the existing assets particularly of land so as to reduce under-employment and bring about increased income levels, and

(iv) Loans are given to the weaker section (marginal and small farmers, agricultural labourers, rural artisans, and members belonging to scheduled casts and scheduled tribes.) for productive purposes with some consumption component so that their productive efficiency does not suffer due to lack of adequate maintenance income. While the banks will have to keep in mind the basic needs to assist increased production by all the banking in the development context implies that the role of banks should contribute to promote various development programme and resource mobilization in the rural sector. The various development programmes could be grouporiented in which loans for group activity may be required or individual oriented in which individuals have to be assisted by loans to undertake investment each on his own. The areas in the command of irrigation projects that require compact area approach, lift irrigation schemes which are group based and individual investment schemes like sinking of a well or purchase of pair of bullocks require different systems of handling. Development programme will also encompass investment lending to add to the productive assets or to improve the productivity of the existing assets such as development of land by leveling and bounding. Development also includes bank loans for improving production with the help of larger and more modern inputs. In this way, development efforts would call for primarily investment lending for creation of assets and secondly for augmenting production from the existing assets as also from additional assets created through investment lending. In the Indian context, development lending has to be in live with the aims, objectives and programme enunciated in the five-year-plans. Thus, bank lending for rural development in India should mean a complementary role by the banks to assist in the implementation of plan programme. Rural banking, in this sense, becomes a handmaid of overall development planning for the rural sector. Considered this way, apart from production and investment loans to increased production and incomes, even schemes for infrastructure development where charges can be levied become bankable propositions.

Credit activities which are undertaken on an individual basis, in an adhoc manner without containing them into the overall plan programme and linking them with infrastructure development, will only result in the misuse of scarce resources and debt becoming a burden instead of a benefit to the borrower. The danger of credit becoming a burden rather than an instrument for uplift is greater in respect of loans to the vulnerable sections of the rural community. Since the poorer groups constitute the largest number, the national objective is naturally to take up development programme for improving the lot of these groups. As a conclusion, banks too will have to take the poorer groups as their main targets for development assistance. When the question is thus to assist the poor, the connotation of banking in the rural areas take a different form. No longer banking can be considered as purely commercial where the banks will decide to assist only those who will be able to make the best use of money lent and repay the loans taken. The role of banks in this situation gets widened and it becomes social banking. Which, would only mean that the banks have to help the socially backward groups not only by providing money but also by arranging for supporting services so that the borrower gets all the inputs required and technical guidance to make proper use of loans. This kind of credit system is really the crux of rural banking in India.

\section{Need of Rural banking Development:}

Rural development may be defined as a process of developing and utilizing natural and human resources, technologies, infrastructural facilities, institutions and organizations, government policies, and programme to improve the quality of rural life towards self-sustenance. In addition to economic growth, this process typically involves charge in popular attitude and in many cases even in customs and beliefs. In a nutshell, the process of rural development must represent the entire gamut of change by which social system moves away from a state of life perceived as unsatisfactory towards a materially and spiritually better conditions of life. 
Micro finance: Emerging Challenges And Opening Vistas

The basic objective of rural development is to organize, develop and utilize the available resources of land, water and manpower in such a manner that the entire population dependent on these resources has an equitable opportunity to meet, as a minimum, its basic needs. Rural development involves:

(i) Improvement in levels of living of the weaker sections of the rural population, as indicated by income, productivity, employment, literacy rate, health and nutrition, infant mortality rate, expectation of life, exposure to mass media, housing, political participation, status of women, supply of safe drinking water and similar other minimum needs etc.

(ii) Eliminating inequality in the distribution of rural wealth and income and economic opportunities.

(iii) Capacity of the rural sector to sustain and accelerate the pace of the above mentioned improvements over time.

\section{How Microfinance Uplifts the Poor?}

Microfinance helps in meeting the need of the poor people by combining the flexibility, sensitivity \& responsiveness of the informal credit system with the strength of technical \& administrative capabilities \& financial resources of the formal credit institutions. It also helps in encouraging the banking activities, both on the thrift as well as credit sides, in a segment of the population that the formal financial institutions usually find difficult to cover. Apart from it, MF builds mutual trust and confidence between bankers and the rural poor people. Microfinance is appreciated by poor people because they don't have any need to pledge something to lenders. It is the very nature of microfinance that no collateral is required to be put off with the lender in the avege of getting monetary assistance. Moreover, this facility is quite convenient to unreached poor who are not having access to financial services in desired manner.

\section{Micro credit-Genesis, Growth and Relevance:}

The approach in reduction of poverty and deprivation has evolved over the past 50 years in various parts of the world and the approached differs from area to area. In 1950s and 1960s large investments in physical and capital and infrastructure were considered as the primary means of development. In the 1970s, it was realized than in addition to physical capital, investment on human resource development like health and education was equally important. In 1970s the buzzword was 'basic needs' and in the 1980s 'structured adjustment' and now the catch phrase include 'poverty reduction', 'governance', 'participation' and 'civil society'*The strategies for poverty alleviation comprised of promoting opportunities for vulnerable section, facilitating empowerment and enhancing security. India has supported social banking for a long time. Policy directions to rapidly expand rural branches, mandate credit allocations for priority sectors (including agriculture), deliver large subsidy oriented credit programmes to serve marginal communities and poor households and control interest rates have been tried for over 35 years. The new generation micro finance was slow in coming to India. Low levels of grants to micro finance institutions, an unfavorable policy environment; substantial traditional banking infrastructure and a search for context specific solutions has constrained rapid scale up. The first breakthrough emerged from policy support to enable informal self-help groups of 15-20 members (mainly women) to transact with commercial banks. These groups build up and rotate savings amongst themselves, open bank accounts and take responsibility for lending and recovering money financed by banks. With the missionary zeal of the National Bank for Agriculture and Rural Development (NABARD), insights gained by NGOs, the increasing enthusiasm of bankers and politicians and emerging successes in repayment and social impacts, this national movement now encompasses 1.4 million such groups (over 20 million members). After the great success of Grameen Bank of our neighboring country Bangladesh, the concept of micro credit has gained momentum. Micro credit/Micro financing has been defined by the 1997 Micro credit Summit as "programmes that provide credit and other financial and business services (including savings and technical assistance) to very poor persons". Micro financing has emerged as a powerful tool to provide micro funds to very poor people for poverty alleviation in the economy. Micro finance is a provision of thrift, credit and other financial services and product of very small amount to the poor in rural, semi-urban and urban areas for enabling them to raise their income levels and improve living standards. According to the UN, in 2002 almost one-fifth of the world population (i.e, 1.3 billion people) was living in extreme poverty, earning less than one dollar a day. Micro credit is being considered as an important poverty alleviator tool all over the world. In many developing economies, especially during the past 10 years, micro credit has been introduced and the concept is gaining momentum. Many examples have been set and especially of Grameen Bank in Bangladesh of Dr. Muhammad Yunus of Chittagong University who felt concern at the pittance earned by landless women after a long arduous day's work laboring for other people. He reasoned that if these women could work for themselves instead of working for others they could retain much of the surplus generated by their labors, currently enjoyed by others. The attention of Micro credit and its role in reducing poverty was further increased when M.Yunus received the Noble Peace Prize. According to him," the poor themselves can create a poverty free world...credit can create self-employment instantaneously". Why wait for others to create a job for you?" A recent survey among 518 Micro credit Institutions in Africa, Latin America, Eastern Europe and Asia reveals that the majority 
Micro finance: Emerging Challenges And Opening Vistas

of the micro credit institutions are found in countries such as Bangladesh, India, Indonesia and Thailand. The extension of services of Micro credit Institutions to poor people in the most populated countries in Asia, such as India and China, is relatively low.

\section{Relevance of Micro credit}

There were countries like India and Israel, which did not believe in the free market economy and continued with their public expenditure programmes. Along with it, attention was made to make India a self sustained economy at least from the viewpoint of agriculture sector. However, it took a long time to realize that if the gains of development have to go to the poor than some different strategy has to be adopted. The countries were providing direct finance earlier also but since the late 1970's it was realized that if one wants benefits to be passed on to the poor ensuring its true use and accountability then micro-credit is the best alternative.

The important difference of micro-credit was that if avoided the pitfalls of an earlier generation of targeted development lending, by insisting on repayment, by charging interest rates that could cover the costs of credit delivery and by focusing on client groups whose alternative source of credit was the informal sector. The support given by the government earlier through its various schemes was also directed but the feeling of accountability was not at all found in the people that time. Now with the presence of Micro-finance Institutions the disbursal and accountability both have improved.

Emphasis shifted from rapid disbursement of subsidized loans to prop up targeted sectors towards the building up of local, sustainable institutions to serve the poor. Micro-credit has largely been a private (nonprofit) sector initiative that avoided becoming overtly political, and as a consequence, has out performed virtually all other forms of development lending.

Target under annual credit plan(Haryana State)

\begin{tabular}{|l|l|l|l|l|l|l|l|l|}
\hline \multicolumn{4}{|c|}{ Agriculture and Allied } & \multicolumn{2}{c|}{ SSI } & \multicolumn{2}{c|}{ Tertiary } & \multicolumn{2}{c|}{ Total } \\
\hline Year & A/c & Amt. & A/c & Amt. & A/c & Amt. & A/c & Amt. \\
\hline $\begin{array}{l}\mathbf{2 0 0 5}- \\
\mathbf{0 6}\end{array}$ & 1447527 & 565562.64 & 66781 & 136303.58 & 198765 & 128683.83 & 1713073 & 830550.05 \\
\hline $\begin{array}{l}\mathbf{2 0 0 6 -} \\
\mathbf{0 7}\end{array}$ & 1905611 & 624933 & 86698 & 149253 & 248996 & 154993 & 2241305 & 929180 \\
\hline $\begin{array}{l}\mathbf{2 0 0 7 -} \\
\mathbf{0 8}\end{array}$ & 2456227 & 1046088 & 127920 & 173770 & 296810 & 197914 & 2880957 & 1417772 \\
\hline $\begin{array}{l}\mathbf{2 0 0 8}- \\
\mathbf{0 9}\end{array}$ & 2448301 & 1282943 & 103096 & 223796 & & & 2864245 & 1775615 \\
\hline
\end{tabular}

\section{Linkage between Rural Banking and Micro Finance}

It must be recognized that without the development of the rural areas, India cannot banish poverty. This is where Micro Finance steps in i.e. availability of institutional credit at low affordable rates which will accelerate the development process leading to grater equality. Role played by NABARD and SIDBI in stimulating rural industrialization and in promotion of various development schemes such as SHG-Bank linkage for supporting SHG through Micro Finance is very significant.

Realizing the importance of credit in the development process, the Government and Reserve Bank of Indiahave taken various steps in this regard and have encouraged Banks to make timely and adequate finance available to poor for agriculture as well as allied activities making institutional credit available to the poor. NABARD is operating the MFDF (Micro Finance Development Fund) and SIDBI (State Industrial Development Bank of India) is operating the SIDBI foundation for Micro-Credit to bring about holistic approach for the development of the Micro-Finance sector.

In the context of India it is experimenting Micro Finance as a tool for Poverty alleviation.Micro Finance focuses on reducing poverty by providing services and other services through Institutions that are funded by various donors and Government subsidies.

The following chart shows the overall progress of Micro-finance during the recent three years: 
Micro finance: Emerging Challenges And Opening Vistas

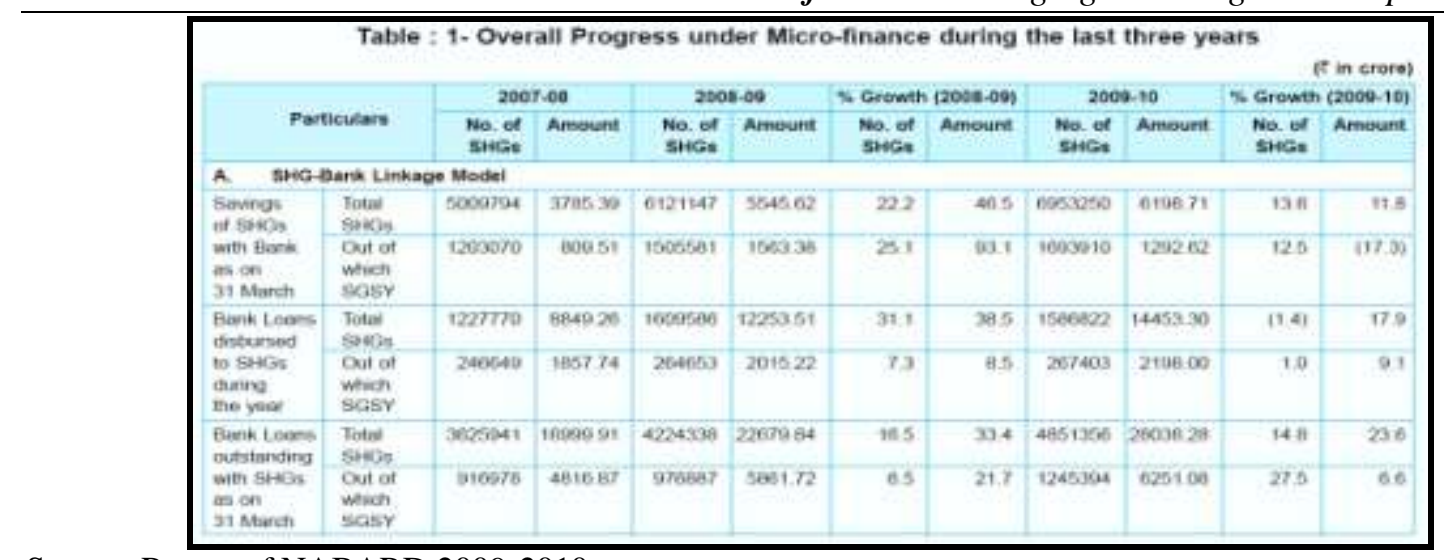

Source: Report of NABARD 2009-2010

Since the major scheme of microfinance is Self Help Groups and we have surveyed women SHG's in gurgaon district. The following chart shows the position of women SHGs as per NABARD report:

\begin{tabular}{|c|c|c|c|c|c|c|c|}
\hline & & & & & & & if stores) \\
\hline \multirow[t]{2}{*}{ Particulars } & \multirow[t]{2}{*}{ rear } & \multicolumn{2}{|c|}{ Total sincs } & \multicolumn{2}{|c|}{$\begin{array}{l}\text { Eleciusive } \\
\text { Women SHGa }\end{array}$} & \multicolumn{2}{|c|}{$\begin{array}{l}\text { Xage of women } \\
\text { SHCs to total SHEs }\end{array}$} \\
\hline & & No. & Amt & No. & Amt & No & Amt. \\
\hline \multirow[t]{2}{*}{ Savieg antod SHOS } & 31.03 .2000 & $612+14 t$ & $5 B+5 * 2$ & 4063021 & 443403 & 79.5 & 1000 \\
\hline & 34002010 & 6053250 & fise 71 & 5310436 & 445960 & $7 \mathrm{te} 4$ & 72.6 \\
\hline \multirow[t]{2}{*}{ Loars disbursed } & $2000-09$ & 1600506 & 1225351 & Bar4578 & 10027.36 & 054 & 859 \\
\hline & $2000-10$ & 15 156a22 & $1445 \times 30$ & 12044ता & 1262931 & Bis. & A0e \\
\hline \multirow[t]{2}{*}{ Loams Ounitandeng } & 31032000 & 4224338 & $22670: 4$ & 3277365 & netease & ne & $3+8$ \\
\hline & 21032010 & 4e51366 & 28039.21 & उล:527 & 2303036 & abs & 12.1 \\
\hline
\end{tabular}

Source: Report of NABARD 2009-2010

As per the table and reports the proportion of women SHG's is very high in total number of SHG's. The graph indicates the amounts of loan outstanding in case of Women SHG's and total SHG's:

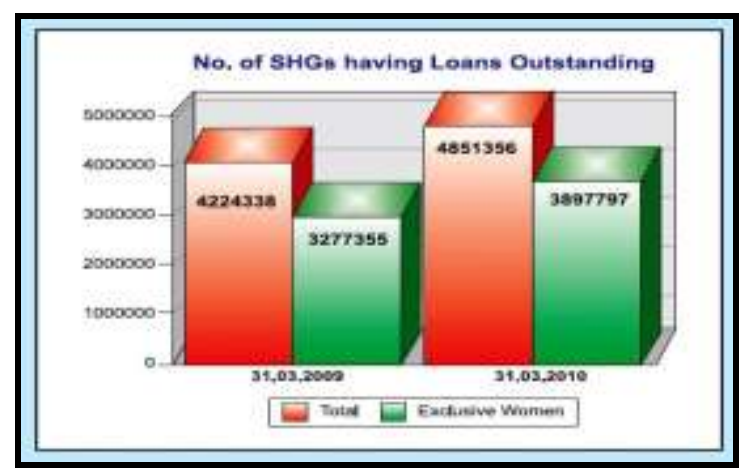

Source: Report of NABARD 2009-2010

\section{Results and Discussion based on the survey}

It has been observed during the field survey that largely the people still depends on moneylenders such as friends, relatives for meeting their small and frequent loan requirement for their survival and growth. These moneylenders exploit them by charging high rate of interest with no value addition. The efforts of the banks, government, NGOs and other such institutes which helps in making an easy access to small amount loans, seems to be ineffective as maximum number of people/respondents were found to be unaware about these programmes. And those who were aware complained that actually, the people who are aware in real terms are still out of the reach of poor people. They also complained that the officials are found to be corrupt and it is practically difficult to avail the credit without inducement.

\section{Suggestions}

As the banking sector is not able to meet the entire credit needs of the poor, it is necessary to encourage the growth of MFI, subject to appropriate regulations.

Though the banking sector has played a significant role for making the provision of finance to the rural masses, but they should also give due weightage for equipping the poor with the necessary skills to become 
efficient money managers and successful entrepreneurs so as to avoid more and more people falling into debt traps and subsequently the death traps.

There is also a need to shift the focus from quantity of credit to the quality of credit.

\section{References:}

[1] Asokan R, Loganathan P, (2006) "Inter Reginal Development of Self Help Groups in India", Kurukshetra (A Journal on Rural Development), Vol. 54, No.11, pp 9-12.

[2] Armendariz Beatriz and Morduch Jonathan, (2007) "The Economics of Microfinance", Massachusetts Institute of Technology, U.S.A Press.

[3] Basu Priya and Srivastava Pradeep, (2005) "Scaling -up Microfinance for India's Rural Poor", World Bank Policy Research Working Paper 3646.

[4] Basu S.C., (2006) "Micro-credit: Towards a Trickle up Approach", The Indian Banker, Vol. I, No. 2, pp 3-6.

[5] Asokan R, Loganathan P, (2006) "Inter Reginal Development of Self Help Groups in India", Kurukshetra (A Journal on Rural Development), Vol. 54, No.11, pp 9-12.

[6] Armendariz Beatriz and Morduch Jonathan, (2007) "The Economics of Microfinance", Massachusetts Institute of Technology, U.S.A Press.

[7] Basu Priya and Srivastava Pradeep, (2005) "Scaling -up Microfinance for India's Rural Poor", World Bank Policy Research Working Paper 3646.

[8] Basu S.C., (2006) "Micro-credit: Towards a Trickle up Approach", The Indian Banker, Vol. I, No. 2, pp 3-6.

[9] Report of NABARD 2009-2010.

[10] Meenakshi B S, (2007) "Microcredit to Nobel", Yojana, pp 63-64

[11] Mishra Chittaranjan, (2005) "SHGs in the Unorganized Garment Sector", Kurukshetra (A Journal on Rural Development), Vol. 53, No.9, pp 43-46.

[12] Morduch Jonathan (1999) “The Microfinance Promise”, Journal of Economic Literature, Vol .37, No.4, pp.1569-1614.

[13] Motwani Ameeta, (2005) “Microfinance: Field Observations", Economic and Political Weekly, Vol. XL, No. 27, pp 3351.

[14] Mukherjee Dhurjati, (2007) "Relevance of Micro Credit: Bangladesh Example Needs to be Emulated", Kurukshetra (A Journal on Rural Development), Vol. 55, No.3, pp 31.

[15] Mulik Nidhi, (2005) "Scoring: The Next Breakthrough in Micro 